\title{
AN ALYSIS OF DISSOLUTION KINETICS BASED ON THE LOCAL ISOTROPIC TURBULENCE THEORY
}

\author{
Lviv Polytechnic National U niversity \\ 12, S. Bandera str., 79013 Lviv, Ukraine
}

Received: J uly 19, 2014 / Revised: September 29, 2014 / Accepted: November 21, 2014

(c) Symak D., Atamanyuk V., Gumnytskyy Y., 2015

\begin{abstract}
The dissolution kinetics of potassium sulfate dissolved in water under pneumatic mixing has been investigated. The mass transfer coefficients were determined by the experiments, as well as on the basis of the local isotropic turbulence theory. The ratio between theoretical and experimental data was found to be satisfying that allows to determine the theoretical mass transfer coefficient to calculate the mentioned process.
\end{abstract}

Keywords: dissolution, kinetics, mass transfer coefficient, intensification.

\section{Introduction}

Dissolution processes are used in many branches of national economy, therefore they are of great importance [1]. Chemical, food, hydrometallurgical, pharmaceutical, galvanic and other industries are interested in studying such processes [2-5]. The data of dissolution process statics and kinetics are the basis for its calculations and designing. In accordance with mentioned data the equilibrium concentrations, degree of equilibrium and time of technological dissolution process are determined. To determine the dissolution time it is necessary to know the kinetic coefficients, namely mass transfer coefficient, which is determined under the laboratory conditions. Commonly the data about mass transfer coefficients are generalized and provided as dimensionless complexes of similarity criteria. The basis of such generalizations is the similarity theory and kinetic results of dissolution in the criteria forms are represented as Eq. (1):

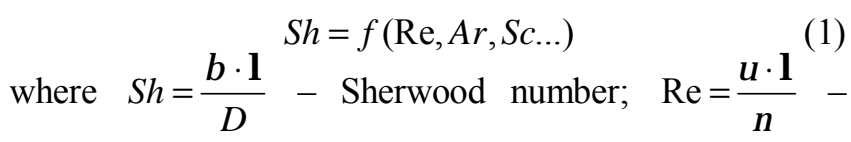
Reynolds number; $\quad A r=\frac{g \cdot \mathrm{l}^{3}}{\mathrm{v}^{2}} \cdot \frac{\Delta \rho}{\rho}-$ Archimedes number; $S c=\frac{v}{D}-$ Schmidt number; $\beta-$ mass transfer coefficient, $\mathrm{m} / \mathrm{s}$; typical linear size, $\mathrm{m} ; D$ - diffusion coefficient, $\mathrm{m}^{2} / \mathrm{s} ; \mathrm{v}$ - velocity of liquid flowing around the solid body, $\mathrm{m} / \mathrm{s} ; \mathrm{v}$ - kinematic viscosity coefficient, $\mathrm{m}^{2} / \mathrm{s}$; $\rho$ - liquid density, $\mathrm{kg} / \mathrm{m}^{3} ; \Delta \rho$ - difference between solid body and liquid densities, $\mathrm{kg} / \mathrm{m}^{3}$.

Archimedes number is used in such a case when it is impossible to determine the value $v$.

Opening of the function in Eq. (1) is given by many investigators, e.g. by R. Petrus et al. [6].

Another method is a theoretical analysis based on the presence of developed turbulence in liquid which is characterized by the turbulence scales from large to small ones [7]. Small-scale turbulence is characterized by homogeneity and isotropy. The mass transfer coefficient $\beta$ is determined based on these properties for the dissolution processes under the mechanical stirring in the solid bodyliquid system [8]:

$$
\beta=0,267\left(\varepsilon_{0} v\right)^{0,25} \mathrm{Sc}^{-0,75}
$$

where $\varepsilon_{0}$ - the average value of the energy refered to the mass unit of the system, $\mathrm{W} / \mathrm{m}^{2}$.

Under the mechanical stirring the energy is determined on the basis of that energy introduced into the system by the mechanical stirrer.

During our investigations the stirring is carried out by a gas phase which considerably changes the system physical parameters due to the formation of liquid-gas emulsion. Momentary isolation of solid particles by gas bubbles may have a positive effect due to the nonstationarity of the dissolution process on the separate particles. Using gas phase has advantages in the case of corrosive medium, dissolution in large volumes and uniform stirring of the whole system.

The aim of this work is to investigate the kinetic regularities of monofractional solid phase dissolution in liquid stirred by gas; experimental determination of mass transfer coefficients taking into account the change of motive force and particles size; comparison of the determined coefficients with $\beta$ values determined on the basis of local isotropic turbulence. 


\section{Experimental}

\subsection{Theoretical Part}

The material balance of dissolution determines the interaction between the solid body and salt masses in the solution and has the form:

$$
M_{0}-M=V \cdot c
$$

where $M_{0}$ - the salt initial mass, $\mathrm{kg} ; M$ - the alt mass at dissolution time $t, \mathrm{~kg} ; V$ - liquid volume, $\mathrm{m}^{3} ; c$ - the salt concentration at time $t, \mathrm{~kg} / \mathrm{m}^{3}$.

Eq. (3) corresponds to the condition when the salt initial concentration is equal to zero in liquid. Introducing the relative values $\eta=\frac{M}{M_{0}}$ and $c_{\max }=\frac{M_{0}}{V}$ we obtain Eq. (4), the equation of a working line, which is a straight dependence

$$
\eta=1-\frac{1}{c_{\max }} c
$$

It determines a degree of deviation from equilibrium value in liquid $c_{s}$.

The process kinetics is determined by the following equation [1]:

$$
-\frac{d M}{d t}=\beta \cdot A \cdot\left(c_{s}-c\right)
$$

where $A$-dissolution surface, $\mathrm{m}^{2}$ and $t$ - time, s.

The values $M, A$ and $t$ are variable in Eq. (5). Using Eq. (4) let us express the concentration by means of the system linear sizes and take into consideration that for the spherical particles

$$
\eta=\frac{M}{M_{0}}=\frac{d^{3}}{d_{0}^{3}}=\varphi^{3}
$$

running values of the solid body mass are equal to

$$
M=N \cdot \rho_{s} \cdot \frac{\pi \cdot d^{3}}{6}
$$

and for the surface

$$
A=N \cdot \pi \cdot d^{2}
$$

where $N$ - particles number; $\rho_{s}-$ the solid body density, $\mathrm{kg} / \mathrm{m}^{3}$.

Substituting (7) and (8) in Eq. (5) and taking into account the value from (6), after transformations we obtain Eq. (9):

$$
-\frac{d(d)}{d t}=\frac{2 \cdot \beta \cdot c_{\max }}{\rho_{s}}\left[\left(\frac{c_{s}}{c_{\max }}-1\right)+\varphi^{3}\right]
$$

To simplify the integration of Eq. (9) we introduce dimensionless linear size $\varphi$; the value $\left(\frac{c_{s}}{c_{m}}-1\right)$ we denote as $a^{3}$. The Eq. (9) has the form:

$$
-\frac{d \cdot\left(\frac{\varphi}{a}\right)}{d t}=\frac{2 \cdot \beta \cdot c_{\max } \cdot a^{2}}{\rho_{s} \cdot d_{0}}\left[1+\left(\frac{\varphi}{a}\right)^{3}\right]
$$

Integration of Eq. (10) within the limits: time $t$ from 0 to $t$ and $\frac{\varphi}{a}$ from $\frac{1}{a}$ to $\frac{\varphi}{a}$ allows to determine the dissolution kinetics of solid particles in the integral form [9]:

$$
\phi\left(\frac{1}{a}\right)-\phi\left(\frac{\varphi}{a}\right)=\frac{c_{\max } \cdot a^{2}}{\rho_{s}} \cdot \frac{2 \cdot \beta}{d_{0}} t
$$

where functions $\phi\left(\frac{1}{a}\right)$ and $\phi\left(\frac{\varphi}{a}\right)$ and $\phi\left(\frac{1}{a}\right) \operatorname{ma} \phi\left(\frac{\varphi}{a}\right)$ are determined by the following dependence [9]:

$$
\phi(x)=\frac{1}{6} \ln \frac{(1+x)^{2}}{1-x+x^{2}}+\frac{1}{\sqrt{3}} \operatorname{arctg} \frac{x \sqrt{3}}{2-x}
$$

Let us substitute $\frac{1}{a}$ or $\frac{\varphi}{a}$ in Eq. (12) instead of $x$.

After we plotted $\phi\left(\frac{1}{a}\right)-\phi\left(\frac{\varphi}{a}\right)=f(t) \quad$ we determined the mass transfer coefficient $\beta$ by means of a slope angle.

The aim of this work is to compare the calculated value with the mass transfer coefficient $\beta$ obtained on the basis of local isotropic turbulence (Eq. (2)). Gas phase provides more uniform stirring of liquid compared with the mechanical stirrer due to the uniform distribution of gas along the apparatus cross-section.

\subsection{Experimental Part}

The experiments concerning potassium sulfate dissolution were carried out at the laboratory plant the main part of which was a vertical cylinder with the diameter of $0.12 \mathrm{~m}$. The cylindrical part is finished by a conic bottom. The grid with holes is situated between the cylindrical and conic parts. The dissolution is carried out periodically, only air is supplied constantly to intensify the process. The air consumption is determined by a rotameter.

The procedure was as follows. Distilled water $\left(2 \mathrm{dm}^{3}\right)$ was loaded into the cylinder while the air compressor was switched on. After establishing the definite value of the air consumption the salt sample was loaded and stopwatch was started. In definite periods of time the samples were withdrawn and the salt concentration in the sample was determined. The experimental temperature was $293 \pm 0.5 \mathrm{~K}$. The fraction of $\mathrm{K}_{2} \mathrm{SO}_{4}$ with the average diameter of $4 \cdot 10^{-3} \mathrm{~m}$ was selected by sieving. The density of the solid phase was $2660 \mathrm{~kg} / \mathrm{m}^{3}$ and saturation concentration was $107 \mathrm{~kg} / \mathrm{m}^{3}$. $150 \mathrm{~g}$ of salt was loaded in the apparatus that was equal to the salt maximum concentration $c_{\max }=75 \mathrm{~kg} / \mathrm{m}^{3}$ under the complete dissolution.

The salt concentration was determined using the ionometric method with the elective electrode. 


\section{Results and Discussion}

Fig. 1 represents the experimental results concerning the change of $\mathrm{K}_{2} \mathrm{SO}_{4}$ concentration in water during the definite time for three different values of gas consumption. The increase in gas consumption intensifies the dissolution process.

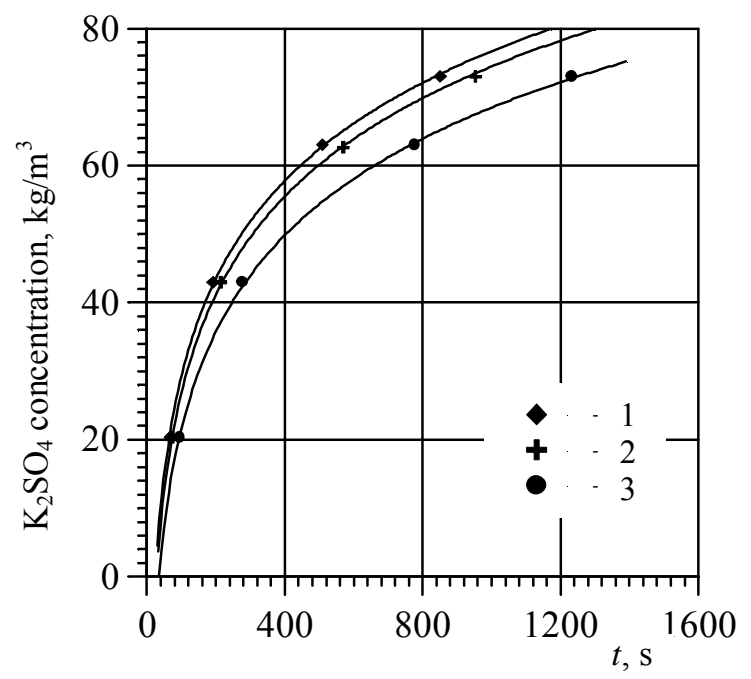

Fig. 1. $\mathrm{K}_{2} \mathrm{SO}_{4}$ concentration vs. time at gas different consumptions $\left(\mathrm{m}^{3} / \mathrm{s}\right): 2.0 \cdot 10^{-3}(1) ; 5.0 \cdot 10^{-3}(2)$ and $1.0 \cdot 10^{-2}(3)$

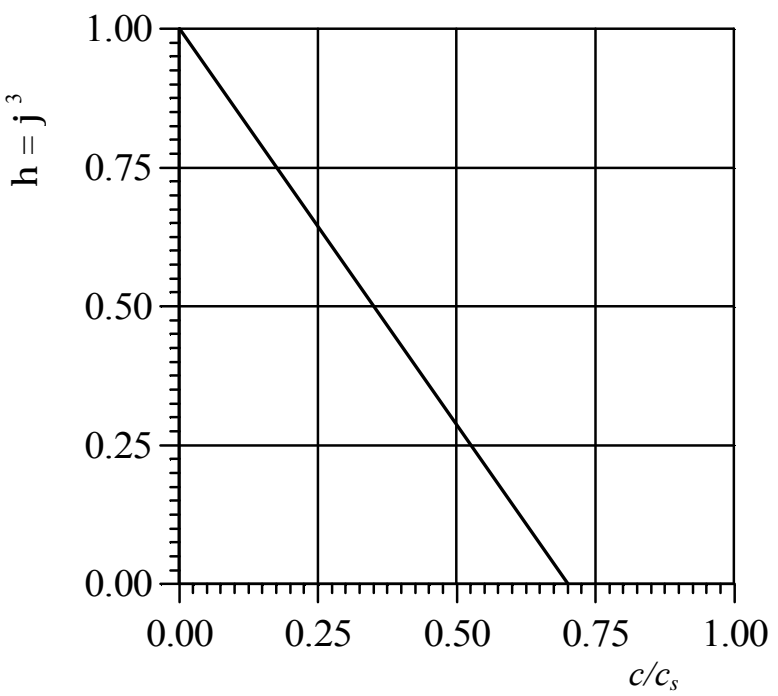

Fig. 2. The working line of the dissolution process

It was mentioned above that dissolution is characterized by statics and kinetics. The statics is described by the material balance of Eq. (4). Let us represent this equation in the dimensionless form: both concentrations $c$ and $c_{\max }$ are divided by the saturation concentration $c_{\text {sat }}$ :

$$
\frac{c}{c_{\text {sat }}}=\bar{c} \text { and } \frac{c_{\max }}{c_{s}}=\bar{c}_{\max }
$$

Apparently the relative concentrations are changed from 0 to 1 and Eq. (4) has the form:

$$
\eta=1-\frac{1}{\bar{c}_{\max }} \cdot \bar{c}
$$

The value $\bar{c}_{\max }$ is equal to 0.7 under the experimental conditions. Fig. 2 represents the working line which is the same for all three cases.

Using the experimental data (Fig. 1) and dependence (11) we determine the values $\phi\left(\frac{1}{a}\right)$ and $\phi\left(\frac{\varphi}{a}\right)$ and $\phi\left(\frac{1}{a}\right)$ ma $\phi\left(\frac{\varphi}{a}\right)$ according to Eq. (12). Values $a$ is 0.753 under the experimental consitions. The difference $\left[\phi\left(\frac{1}{a}\right)-\phi\left(\frac{\varphi}{a}\right)\right]$ as a function of time $t$ is represented by the plot (Fig. 3) depending on gas consumption.

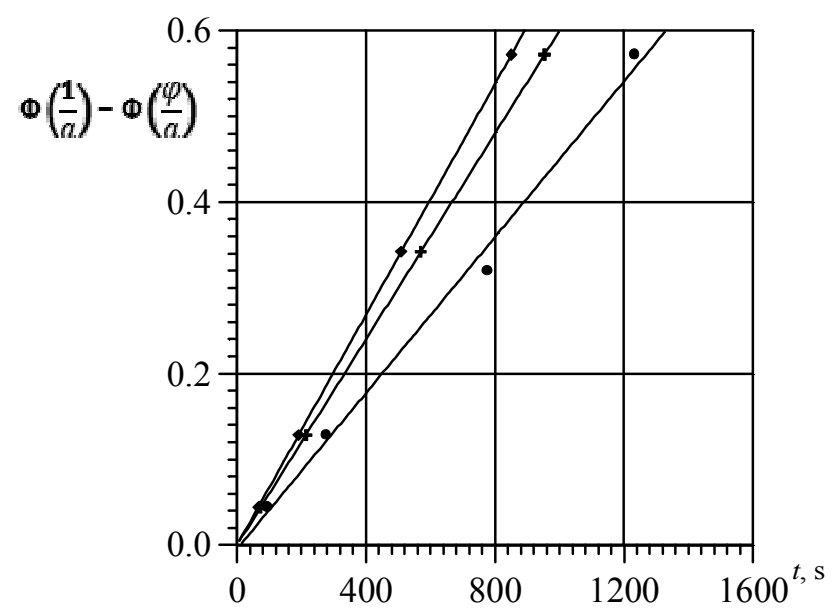

Fig. 3. $\left[\phi\left(\frac{1}{a}\right)-\phi\left(\frac{\varphi}{a}\right)\right] v$ s. dissolution time $t$

The slope angle $\gamma$ has a value of $\operatorname{tg} \gamma=\frac{c_{\max } \cdot a^{2}}{\rho_{s}} \cdot \frac{2 \cdot \beta}{d_{0}}$. Hence, $\beta=\operatorname{tg} \gamma \cdot \frac{\rho_{s} \cdot d_{0}}{c_{m} \cdot a^{2}}$

We compare the obtained results with theoretically calculated values according to Eq. (2) on the basis of the local isotropic turbulence theory. The main value affecting the mass transfer coefficient $\beta$ under other constant parameters is a specific energy $\varepsilon_{0}$. It is determined as follows:

$$
\varepsilon_{0}=\frac{E}{m}=\frac{V_{g} \cdot \Delta p}{m}=\frac{V_{g} \cdot \rho_{\text {sus }} \cdot g \cdot H}{m}
$$

where $\Delta \rho$ - pressure loss, $\mathrm{Pa} ; m$ - suspension mass, $\mathrm{kg}$; $V_{g}-$ gas consumption, $\mathrm{m}^{3} / \mathrm{s} ; \rho_{\text {sus }}-$ suspension density, $\mathrm{kg} / \mathrm{m}^{3}$ and $H-$ suspension height, $\mathrm{m}$. 
Theoretical and experimental values of the mass transfer coefficient $\beta$

\begin{tabular}{|c|c|c|c|}
\hline$V_{g}, \mathrm{~m}^{3} / \mathrm{s}$ & $\varepsilon_{0, \mathrm{~W}} / \mathrm{kg}$ & $\beta_{\text {theor }}, \mathrm{m} / \mathrm{s}$ & $\beta_{\text {exp }}, \mathrm{m} / \mathrm{s}$ \\
\hline $2 \cdot 10^{-3}$ & 1.768 & $5.96 \cdot 10^{-5}$ & $5.8 \cdot 10^{-5}$ \\
\hline $5 \cdot 10^{-3}$ & 4.42 & $7.49 \cdot 10^{-5}$ & $7.5 \cdot 10^{-5}$ \\
\hline $1 \cdot 10^{-2}$ & 8.82 & $8.9 \cdot 10^{-5}$ & $8.4 \cdot 10^{-5}$ \\
\hline
\end{tabular}

The coefficient of molecular diffusion $D$ is equal to $1.12 \cdot 10^{-9} \mathrm{~m}^{2} / \mathrm{s}[2]$.

The calculated theoretical values of the mass transfer coefficient are represented in Table depending on the gas consumption. They are also compared with the experimental ones. The data given in Table show the satisfactory correlation between the experimental and theoretical values of the mass transfer coefficient $\beta$ within the range of specific energy $1.7<\varepsilon<8.8 \mathrm{~kW} / \mathrm{kg}$. Thus, the values calculated according to Eq. (2) may be used for calculations of the dissolution process with a satisfactory degree of reliability to determine apparatus size and dissolution time.

\section{Conclusions}

The dissolution kinetics of the solid body in the apparatus with the pneumatic agitation was investigated and the dependence of concentration on time was established.

We solved the differential kinetic equation while changing the particle diameter and process motive force.

The mass-transfer coefficients were determined during dissolution and they were compared with the theoretical values obtained on the basis of local isotropic turbulence.

\section{References}

[1] Akselrud G. and Molczanow A. Rozpuszczanie ciał stałych. Wyd. Naykowo - Techniczne, Warszawa 1981.

[2] Zdanovskyj A.: Galurgia. Khimiya, Leningrad 1972.

[3] Shohin I., Ramenskaya G., et al.: Vestnik Voroneg. Gos. Univ.: Khimiya, Biologia, Farmacia, 2009, 2, 199.

[4] Lucyk V.: Kinetika Hidroliticheskogo i Okislitelnogo Rastvorenia. Izd. Tverskogo Gos.Techn.Univ., Tver 2009.

[5] Babenko Y. and Ivanov E.: Teor. Osnovy Khim. Techn., 2013, 47, 624 .

[6] Petrus R., Akselrud G, Gumnitsky Y. and Piontkowski W.: Wymiana masy w układzie ciało stałe - ciecz. Wyd. Politechniki Rzeszowskiej, Rzeszow 1998.

[7] Landau L. and Lifshic B.: Hidrodynamika, T.VI. Nauka, Moskwa 1988.

[8] Braginskyj L., Begachev V. and Barabash V.: Peremeshivaniye v Zhidkih Sredah. Khimiya, Leningrad, 1984.

[9] Dwight H.: Tablicy Integralov i Drugie Matematicheskie Formuly. Nauka, Moskwa 1977.

\section{АНАЛІЗ КІНЕТИКИ РОЗЧИНЕННЯ НА ОСНОВІ ТЕОРІї ЛОКАЛЬНОЇ ІЗОТРОПНОЇ ТУРБУЛЕНТНОСТІ}

Анотація. Досліджено кінетику розчинення сульфату калію у воді при пневматичному перемішуванні системи. Визначено коефічієнти масовіддачі на основі експериментальних досліджень та теоретично на основі теоріі локальної ізотропної турбулентності. Показано задовільне співвідношення теоретичних та експериментальних даних, щзо дає можсливість теоретичного визначення коефімієнта масовіддачі з метою розрахунку даного прочесу.

Ключові слова: розчинення, кінетика розчинення, коефіцієнт масовіддачі, інтенсифікаиія. 